\title{
TSUKAMOTO FUZZY METHOD IN DECISSON SUPPORT SYSTEM DESIGN
}

\author{
Arridha Zikra Syah \\ Department of Information system, STMIK Royal Kisaran \\ Email: azsyra@gmail.com
}

\begin{abstract}
PT Pinus Merah Abadi is one of the distributor companies in Indonesia engaged in selling snacks such as snacks and wafers with the Nabati brand. Every month the company offers increased incentives for its employees with predetermined conditions or targets. But in the process, the incentive calculation is managed manually using criteria by the General Affair Personnel who then data the results of the manual calculation are sent to the central office to obtain the disbursement of funds. Sometimes the results of these decisions are too rigid. The method used to solve this problem is the RAD method and each stage is adjusted accordingly based on the Tsukamoto fuzzy algorithm. From this study, an application of decision support systems was obtained that could support decision making to increase incentives that were more appropriate in human consideration.
\end{abstract}

Keywords: decison support system design; incentive calculation; tsukamoto method

Abstrak: PT Pinus Merah Abadi merupakan salah satu perusahaan distributor di Indonesia yang bergerak di bidang penjualan makanan ringan seperti snack dan wafer dengan merk nabati. Setiap bulan perusahaan menawarkan insentif yang meningkat bagi karyawannya dengan kondisi atau target yang telah ditentukan. Namun dalam prosesnya, perhitungan insentif dikelola secara manual menggunakan kriteria oleh personil urusan umum yang kemudian data hasil perhitungan manual dikirim ke kantor pusat untuk mendapatkan pencairan dana. Terkadang hasil dari keputusan ini terlalu kaku. Metode yang digunakan untuk memecahkan masalah ini adalah metode RAD dan dalam setiap tahap disesuaikan sesuai berdasarkan algoritma fuzzy Tsukamoto. Dari studi ini, sebuah aplikasi dari sistem pendukung keputusan diperoleh yang dapat mendukung pengambilan keputusan untuk meningkatkan insentif yang lebih tepat dalam pertimbangan manusia.

Kata kunci: metode tsukamoto; peningkatan insentif, perancangan sistem pendukung keputusan

\section{INTRODUCTION}

To improve the quality of potential and qualified employees, the Company usually performs a variety of ways through various processes and provisions of the company to achieve the desired company goals. One method used to provide work motivation in the form of increased rewards in the form of incentives [1]. Incentives and bonuses also include the injection of enthusiasm and motivation for employees to work diligently and seriously, therefore the company must also have thought about how much bonuses and incentives are intended for employees who have carried out their duties diligently to achieve the company goals [2]. Incentives are given to employees in return for out-of-salary 
services. Isentif is given based on the results of work with the intention that employees want to work better and in order to achieve a higher level of performance, so that a person wants to work in earnest if there is a high spirit of work inside. Incentives are intended to meet the needs of employees and their families[3].

Likewise with PT Pinus Merah Abadi is one of the distributor companies in Indonesia engaged in the sale of snacks such as snacks and wafers with the Nabati brand. this company is a national company that has many branches throughout Indonesia to distribute its merchandise, this company also every month issues incentives for its employees with predetermined terms or targets every year with the terms and targets determined and intense competition from employees other employees. But in the process, the calculation of incentive increases is managed manually by the manager. Then the manager promotes the names of eligible employees based on these calculations to the head office. Based on a preliminary study conducted on the company regarding the promotion of incentive enhancement, many employees were eligible but due to lack of points in one criterion, the employee did not get a promotion.

This requires a system that uses reasoning to support the decision to increase staff at the PT Pinus Merah Abadi branch office. So that every employee who is proposed to get an incentive increase can be calculated following more humane considerations. Thus, employees can be considered for obtaining their rights even though all conditions are not met in full. To simplify the calculation toolbox is used. Increasing incentives is very important to be managed and run by the company, so the Implementation of the Tsukamoto Fuzzy Method in Consideration of Increasing Incentives that will be implemented at the branch company PT Pinus Merah Abadi can provide a different perspective for companies to make decisions regarding promotion of this employee increase [4]. Decision support system applications can provide the best output with fuzzy logic methods that play an active role in determining the results of the set of values of each input variable [5]. The system with fuzzy models can provide alternatives and accelerate the results in the calculation of the desired output [6]. The model of decision support system with fuzzy method emphasizes knowledge as a source of knowledge. The Tsukamoto method is an extension of monotonous reasoning. In the Tsukamoto method, each consequent to the IF-THEN rule must be represented by a fuzzy set with a monotonous membership function. As a result, the output of inference results from each rule is given expressly (crisp) based on apredikat (fire strength). The end result is obtained using a weighted average [7]. Fuzzy logic is one method to perform system analysis that contains uncertainty. Fuzzy logic mimics a human thinking way called reason, where reason can explain and identify things automatically. In this research used inference method of Fuzzy Tsukamoto system. The design of the system for obtaining output is carried out in stages (a) The establishment of the Fuzzy set, (b) Application of the implication function, (c) The composition of the rule, (d) the affirmation (Defuzzification) [8][9]. For the last step for this method used Beirut function [9]:

$\mathrm{Z}=\frac{\sum_{\mathrm{k}=\text { rule 1 }}^{\mathrm{n}=\text { rule 107 }}\left(\begin{array}{l}n \\ k\end{array}\right) \operatorname{\alpha pred}_{k} \times Z_{n}}{\sum \alpha \operatorname{pred}_{k}}$ 
For the suitability of decision support system results, appropriate application is required, therefore it requires a method of designing the right information system. One of the quick and user-friendly system design is rapid application development (RAD) method [10].

\section{METHOD}

Methods used include research and design methods. The research methods used are qualitative. The planning method defined is the Rapid Application Development (RAD) method. Both methods are used continuously and at the same time, in conjunction with the achievement of research

A qualitative research method is used to uncover the truth of the situation decision making in PT. Pinus Merah Abadi. With this method, the researcher can reveal the data that portrayal of all the needs used in the design. In this method, data collection is done using document collect method such as database techniques, containt analize and interview. This method is used to got a spesific requared of system. The spesification based on the partisipant form the current company incude Personalia General Affair and twenty seven employe. The data contained in the picture obtained conclusions about the picture of needs.

Assessment criteria used for promotion of increased incentives, namely: Sales value (SV), Target sales of all products based on the target achieved by each gabble; Sales Value-NPL (SVNPL), It is a sales target for new products launched by the company; effective Performance (EP), Standard Target per route; Items per transaction (IPT), Summation items per transaction target listed in the sales invoice; ROA THE NPL KSNI SKU, The number of new target achievements is at least $50 \%$ of all targets.

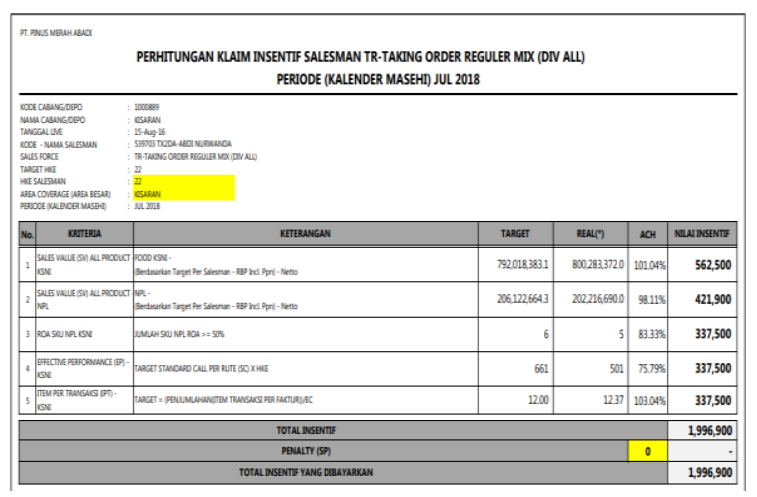

Image 1. Image Example

Based on the data obtained about alternatives, a suitable example is taken for the company and this calculation can be seen as image 1 . From the above data obtained some fuzzy variables adapted to the criteria owned, Yaitu sales value (SV), Sales value-NPL (SV-NPL), effective Performance (EP), item per transaction (IPT), ROA SKU NPL.

Meanwhile, for designing used Raphid Application Development method to design applications in an information system such as a decision support system. From the data obtained, analysis needs. In the analysis of such needs, the process is needed by using the fuzzy algorithm Tsukamoto. From the analysis of these needs, the design is designed using UML and implemented in Web programming.

The fuzzification algorithm tsukamoto consist of four mayor step as said before. But before use the steps, the preparation is needed. The preparation step carried out before the move to the Tsukamoto method is to determine the value of the universe and the fuzzy membership set. They can be seen in the images 2-7: 


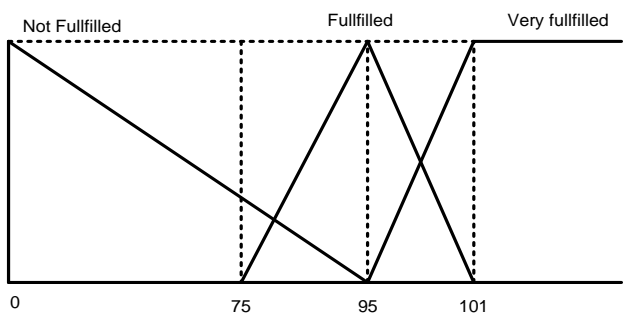

Image 2. Variable curve amount SV

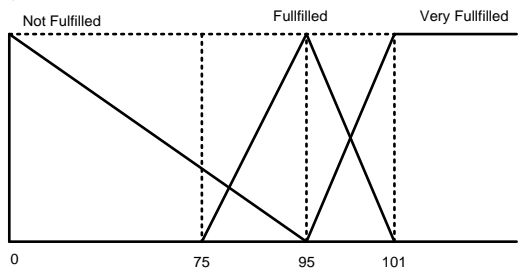

Image 3. Sales Value-NPL

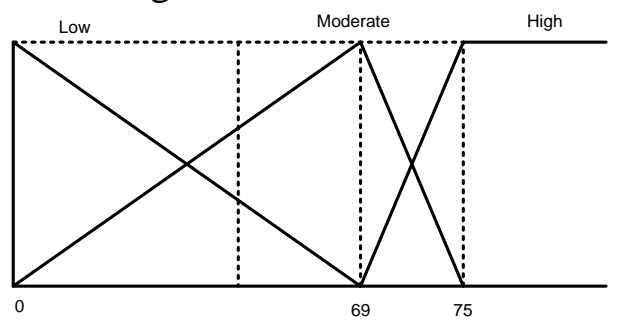

Image 4. Performance

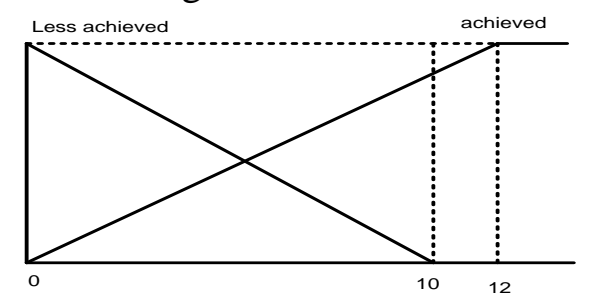

Image 5. Item Per Transaction

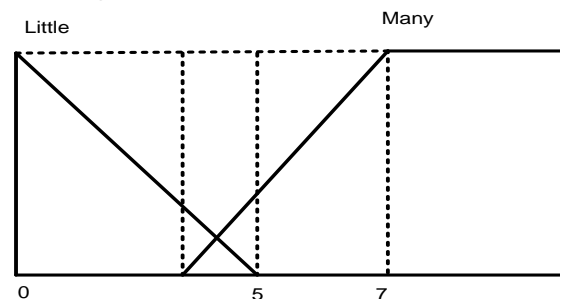

Image 6. ROA THE NPL KSNI SKU

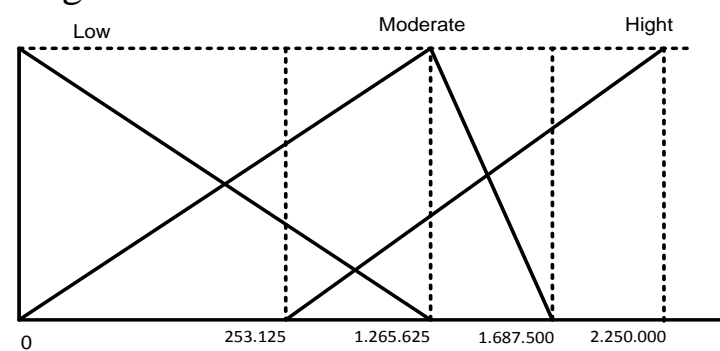

Image 7. Incentive Increase membership function as output function membership

Step 1 is fuzzifications. Calculations Fuzzifikasi use linear functions. The fuzzy value of each set for a corresponding variable comes from the data in which $\mathrm{SV}=101,00, \mathrm{SV}$ $\mathrm{NPL}(\mathrm{SVN})=98,11, \mathrm{EP}=75,79, \mathrm{IPT}=$ 12,37, ROA SKU NPL KSNI (ROA)= 5.00. The Fuzzifikasi result for each variable and the corresponding membership set can be seen in the following table 1 .

Table 1. Fuzzification result

Var. Membership Set $\begin{gathered}\text { Membership } \\ \text { Function }\end{gathered}$

\begin{tabular}{cccc}
\hline SV & Unfulfilled & Linear Desc. & 0,00 \\
\hline SV & Fulfilled & Triangle & 0,00 \\
\hline SV & Highly Fulfilled & Linear Asc. & 1,00 \\
\hline SVN & Unfulfilled & Linear Desc. & 0,00 \\
\hline SVN & Fulfilled & Triangle & 0,38 \\
\hline SVN & Highly Fulfilled & Linear Asc. & 0,62 \\
\hline EP & Low & Linear Desc. & 0,00 \\
\hline EP & Are & Triangle & 0,00 \\
\hline EP & High & Linear Asc. & 1,00 \\
\hline IPT & Less Achieved & Linear Desc. & 0,00 \\
\hline IPT & Reached & Linear Asc. & 1,00 \\
\hline ROA & Little & Linear Desc. & 0,00 \\
\hline ROA & Many & Linear Asc. & 1,00 \\
\hline & & &
\end{tabular}

Step 2 is Ruled based, in this steps the rules or knowledge is set. Base on step 2, the next step is inference. Based on the obtained data and the number of sets each output variable. This employee improvement Decision support system consists of 107 rules. From rules, 107 times inferensce is done. The Operator used to connect each input condition is OR. This acquires outputs equal to the facts found in PT. Pinus Merah Abadi.

Last step is defauzzification. From the rule is inference and then 
defuzzification and meme by the value of cripts for the income of Lord of servants as much as Rp. $2,134,917.21$.

$Z=\frac{2.241 .663 .07,50}{105}$
$Z=2.134 .917,21$

\section{RESULT AND DISCUSSION}

Analysis of the current decision support system based on data from the company. The old information flows regarding the increase in incentives at PT Pinus Merah Abadi Branch office are as follows: The employee noted the achievement of the incentive increase manually on the board Monitoring Board that has been provided by the company; PGA (Personalia General Affair) calculates calculation of achievement criteria of employee incentive increase; PGA makes the achievement report, as well as the upgrade recommendation then, asks the manager's approval, then, sends it to the head office via email; Head Office through personnel receiving the email and then made evidence for incentive disbursement; Once the incentive disbursement sheet is made, the head office sends it back via email to the corresponding PGA branch office; Then PGA receives his email and prints out the proof of disbursement of incentives and then handed over to the manager in advance for the signature process, which is then handed over to the employees.

From the analysis of the decisionmaking, the system is seen that the calculation process is done all still manually. Besides, the calculation of the system still uses very rigid calculations. Also, some problems exist in this system. In this section, the research design is no longer contained but is focused on the result of the research that has been carried out.

The analysis produces a form of system design that suits the needs of the company. the design includes Selfesteem from implement-tations to login menu; Create, Read, Update and delete alternatives; Create, Read, Update and delete criteria; Create, Read, Update and delete ruled; and then Create, Read, Update and delete the current user. To output, the system process provides all the calculations include: Fuzzifikasi, Inference, defuzzification.

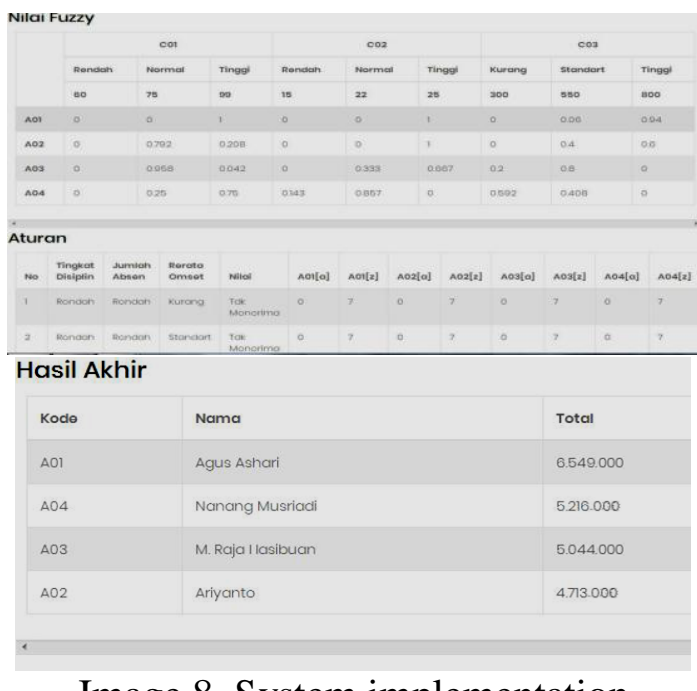

Image 8. System implementation

The results of the application of decision support system and manual calculation showed a number that is almost equal to the level of double-digit accuracy.

\section{CONCLUSION}

The resulting application can calculate based on criteria that can be adjusted to the company's condition. Likewise, the alternative can be adapted to the conditions that the company will encounter later. While the rule can also adjust the results of local decisions. The 
employee can immediately determine the process of calculating the employee lifting system because calculations are done by the branch manager where the employees work and the results can be seen by employees directly through the web provided.

\section{BIBLIOGRAPHY}

[1] Zainal Arifin, "Pengaruh Insentif Terhadap Kinerja Karyawan PT Idec Wood Di Tarakan," J. Adm. Bisnis, vol. 5, no. 4, pp. 1292-1303, 2016, [Online]. Available: https://ejournal.adbisnis.fisipunmul.ac.id/site/wp-content/ uploads/2017/11/Jurnal Zainal Arifin (11-14-17-02-30-19).pdf.

[2] P. Cahyono Sigit, "Perancangan sistem insentif menggunakan metode perencanaan insentif kelompok," Ilm. Tek. Ind., vol. 10, no. 1, pp. 2934, 2011, [3] T. Setiawan and D. Anggriawan, "Bagaimana Analisis Pendapatan Dan Biaya Relevan Atas Bisnis Online?," Coopetition J. Ilm. Manaj., vol. 9, no. 2, pp. 115-119, 2018 ,

[4] A. Z. Syah and R. Rizaldi, "Implementasi Metode Fuzzy Tsukamoto Pada Pertimbangan Peningkatan Insentif Karyawan Perusahaan Cabang PT Pinus Merah Abadi," Pros. Semin. Nas. Ris. Inf. Sci., vol. 1, no. September, p. 986, 2019,

[5] Rizaldi, D. Anggraeni, R. Rahim, A. Z. Syah, and Y. Siagian, "Decision Support System for Formula Milk Selection Based on Nutrition Value Using Tahani Model Database Fuzzy Method," J. Phys. Conf. Ser., vol. 1114, no. 1, 2018,

[6] S. Aswati, N. Mulyani, Y. Siagian, and A. Z. Syah, "Sistem Pendukung Keputusan Penerima Beasiswa Pendidikan Yayasan (Studi Kasus STMIK Royal) dengan Metode Simple Additive Weight," Semin. Nas. Sist. Inf. Indones., no. November, pp. 453-462, 2015.

[7] A. Prayogi, E. Santoso, and Sutrisno, "Sistem Pendukung Keputusan Untuk Penentuan Jumlah Produksi Nanas Menggunakan Metode Fuzzy Tsukamoto (Studi kasus PT.Great Giant Pineapple)," J. Pengemb. Teknol. Inf. dan Ilmu Komput., vol. 2, no. 6, p. 6, 2018.

[8] S. Y. Irianto and T. Informatika, "Penerapan Metode Fuzzy Inference System Tsukamoto Pada Sistem Pendukung Keputusan Untuk Penerimaan Beasiswa," J. Inform., vol. 16, no. 1, pp. 10-23, 2016.

[9] V. Sutojo, T; Mulyanto, Edi; Suhartono, "Kecerdasan Buatan." pp. 211-235, 2011, Available: https://books.google.co.id/books?id= R7qgAQAACAAJ\&dq=kecerdasan+ buatan+sutojo\&hl=id\&sa $=X \&$ ved $=2$ ahUKEwiSmMm7yavqAhWNeX0K HVTRAeIQ6AEwAHoECAAQAQ.

[10] S. Aswati and Y. Siagian, "Model Rapid Application Development Dalam Rancang Bangun Sistem Informasi Pemasaran Rumah (Studi Kasus: Perum Perumnas Cabang Medan," Sesindo, pp. 317-324, 2016, [Online]. Available: http://is.its.ac.id/pubs/oajis/index.ph p/home/detail/1676/MODEL-

RAPID-APPLICATIONDEVELOPMENT-DALAMRANCANG-BANGUN-SISTEMINFORMASI-PEMASARANRUMAH-STUDI-KASUS-PERUMPERUMNAS-CABANG-MEDAN. 